\title{
When polarization hits corporations: the moderating effect of political ideology on corporate activism
}

\author{
Nuria Villagra; Jorge Clemente-Mediavilla; Carlota López-Aza; Joaquín Sánchez- \\ Herrera
}

Cómo citar este artículo:

Villagra, Nuria; Clemente-Mediavilla, Jorge; López-Aza, Carlota; Sánchez-Herrera, Joaquín (2021). "When polarization hits corporations: the moderating effect of political ideology on corporate activism". Profesional de la información, v. 30, n. 6, e300602.

https://doi.org/10.3145/epi.2021.nov.02

Artículo recibido el 22-05-2021 Aceptación definitiva: 21-09-2021

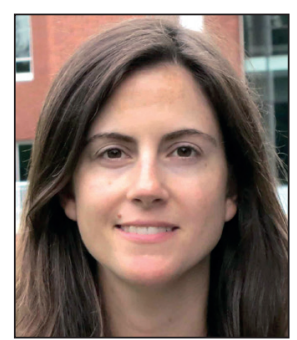

Nuria Villagra

https://orcid.org/0000-0002-2613-1530

Universidad Complutense de Madrid Facultad de Ciencias de la Información Avda. Complutense, 3 28040 Madrid, Spain nuriavillagra@ucm.es

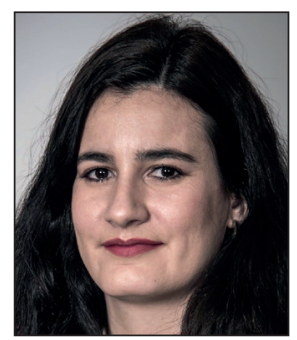
Carlota López-Aza
https://orcid.org/0000-0002-7723-066X
Universidad Complutense de Madrid
Facultad de Ciencias Económicas y
Empresariales
Campus de Somosaguas
28223 Pozuelo de Alarcón (Madrid), Spain carlop14@ucm.es

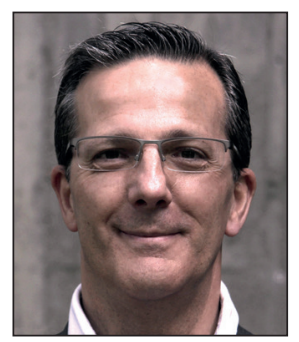

Jorge Clemente-Mediavilla $\triangle$ https://orcid.org/0000-0002-9819-1129

Universidad Complutense de Madrid Facultad de Ciencias de la Información Avda. Complutense, 3 28040 Madrid, Spain jclemen@ucm.es

\section{Abstract}

Traditionally, it has been argued that companies should maintain a neutral stance on issues of a social or political nature, especially controversial ones. However, in recent years, corporations have begun to adopt clear positions on sensitive and polarizing social and political issues. This new phenomenon, called corporate activism, is beginning to gain prominence in corporate strategies, which now extend beyond business objectives and sometimes may go against the beliefs held by many customers. To date, studies aimed at identifying whether these types of actions benefit or harm companies are scarce, and none of them have focused on consumer perceptions. Adopting the latter approach, this work identifies the antecedents and effects of corporate activism, and the influence that political ideology can have as a variable moderating these effects. Analysis of a sample of 1,521 individuals representative of the Spanish population using a structural equation model yielded the following results: (i) institutional and corporate credibility and authenticity act as antecedents of corporate activism, (ii) when credibility in institutions diminishes, consumers perceive that corporations should be more involved in social and political affairs, even when controversial or polarizing, (iii) reputation and brand equity are considered effects of corporate activism, and (iv) political ideology acts as a variable moderating these effects, in such a way that individuals with a more conservative ideology do not appreciate that companies that get involved in activist initiatives will enjoy positive consequences on their reputation and brand equity, while individuals with more liberal views do perceive such positive effects. These findings help companies to guide their strategic decisions, especiaIly those related to corporate social responsibility (CSR), as well as help governments and institutions to understand the social changes that are taking place and understand the role that consumers expect corporations to play today.

\section{Keywords}

Corporate activism; Social polarization; Political ideology; Brand equity; Corporate reputation; Authenticity; Credibility; Socially responsible consumption.

\section{Funding}

This paper reflects the results of a project funded by Banco de Santander and the Complutense University of Madrid, with reference $\mathrm{n}$ - PR87/19-22686. 


\section{Introduction}

During recent decades, companies have increasingly developed their social responsible dimension through CSR, philanthropy, or social actions, engaging in issues that enjoy support from or consensus among their stakeholders (Monfort; Villagra; López-Vázquez, 2019; Rim; Lee; Yoo, 2020; Vredenburg et al., 2020) while avoiding positioning themselves on controversial or polarizing social and political issues, understanding that this could have negative effects. However, in recent years, more and more examples of companies positioning themselves on social, political, and environmental issues that are not directly related to their business activity have emerged. This phenomenon, called corporate activism, represents a trend in corporate strategy. Sarkar and Kotler define it as

"business efforts to promote, impede, or direct social, political, economic, and/or environmental reform or stasis with the desire to promote or impede improvements in society" (Sarkar; Kotler, 2018, p. 568).

Although its adoption involves risks such as lower levels of consumer brand identification (Mukherjee; Althuizen, 2020) and supposes the loss of a fraction of the customers who do not support such positions (Dodd; Supa, 2015; Hydock; Paharia; Weber, 2019), more and more companies are adopting these strategies since there is a demand from stakeholders for companies to become involved and transparently convey their position on social and political issues (Nalick et al., 2016; Wettstein; Baur, 2016; Wilcox, 2019).

Given that this is a new topic, it is necessary to analyze the concept in depth and propose models to evaluate and treat it (Vredenburg et al., 2020). In this regard, recent studies showing that activism results in changes in consumer attitudes towards brands (Corcoran; Newman; Devasagayam, 2016; Dodd; Supa, 2014; Korschun et al., 2019; Mukherjee; Althuizen, 2020; Parcha; Kingsley-Westerman, 2020) or its impact on brand equity (Korschun; Martin; Vadakkepatt, 2020; Vredenburg et al., 2020) or reputation (Den-Hond et al., 2014) have emerged.

While social and political aspects are taking on a greater role in the corporate sphere, we observe a society that is increasingly involved in these issues and becoming more polarized, especially on political issues (Masip; Suau; Ruiz-Caballero, 2020; Jost, 2006). Therefore, the political ideology of the consumers is a factor that may moderate the effects of such corporate activism initiatives.

A framework is proposed herein to reveal the relationships between four key communication and marketing research concepts (credibility, authenticity, corporate reputation, and brand equity) related to corporate activism. The credibility of organizations and authenticity are two antecedents that influence the assimilation of corporate activism. On the other hand, the effects of this type of action on reputation and brand equity are analyzed, considering the political ideology of the consumer as a moderating variable. In a society that is increasingly polarized on political issues (Hydock; Paharia; Weber, 2019), work is needed to analyze how ideology affects the field of marketing (Ulver; Laurell, 2020). Specifically, an important contribution of this work is to study how political ideology moderates the effect of a corporate activism initiative on the reputation or brand equity as perceived by the consumer.

The remainder of this manuscript is structured as follows: In the theoretical framework, we highlight the growing trend of corporate activism and the lack of specific studies on the subject. Likewise, we delve into previous works on credibility and authenticity (since they act as antecedents of this phenomenon), and on corporate reputation and brand equity (effects of corporate activism), reviewing studies that have considered the political ideology of the consumer as a moderating variable. Thereafter, we carry out an empirical study that delves into all these relationships from the consumer's point of view, and comment on its results to finally present the implications of this work for both the academic and corporate fields.

\section{Theoretical framework}

The recent years have seen a trend in which companies and their managers take sides on controversial social and political issues that are not directly related to their business activity (Manfredi-Sánchez, 2019) such as LGBTQIA+ rights, racism, immigration, gun control, and climate change. Eilert and Nappier-Cherup (2020, p. 463) define corporate activism as

"a company's willingness to take a stand on social, political, economic, and environmental issues to create societal change by influencing the attitudes and behaviors of actors in its institutional environment."

This trend responds to a social demand (Hoppner; Vadakkepatt, 2019). Consumers and society in general want companies to take sides on sociopolitical issues to drive social change beyond profit-making and transparently communicate their position on these issues (Nalick et al., 2016; Wettstein; Baur, 2016; Wilcox, 2019). Moreover, in their purchase decisions, consumers choose brands with values and behaviors that they trust (Stanley, 2020).

Therefore, corporate activism must involve company performance outcomes such as a positive impact on sales, consumer loyalty, brand equity, or reputation (Korschun; Martin; Vadakkepatt, 2020; Vredenburg et al., 2020) while contributing to promoting social change (Eilert; Nappier-Cherup, 2020; Moorman, 2020; Stephan et al., 2016) as it influences the attitudes and behaviors of different social actors (government, other companies, and NGOs).

Despite the positive effects that this implies, given that these issues are controversial and debatable, a company that adopts such a strategy must also bear in mind the associated risks (Pintado-Blanco; Sánchez-Herrera; López-Aza, 2020). 
On the one hand, it can lead to public rejection and mistrust if the position adopted is not credible or is perceived as opportunistic. In such cases, it is said that the company is "woke washing"; that is, that the cause is not aligned with their purpose, values, and behaviors (Sobande, 2019; Vredenburg et al., 2020). For this reason, it is very important that the position adopted and its communication be reflected in corporate practices (Dodd; Supa, 2014) and show a real commitment to social change beyond the short-term benefit to the company (Sarkar; Kotler, 2018; Wettstein; Baur, 2016). On the other hand, as pointed out by Moorman (2020) and Vredenburg et al. (2020), when dealing with issues that polarize public opinion, a fraction of consumers will not share these values, which can cause their loss as clients or have a negative impact on their purchasing intentions (Dodd; Supa, 2015).

The literature does not reach a consensus on whether companies can legitimately position themselves on controversial sociopolitical issues that polarize public opinion (Dodd; Supa, 2014; Chang, 2017; Lin, 2018; Moorman, 2020; Nalick et al., 2016), which were previously reserved for governments or other institutions such as NGOs. The contribution of this work is to study how consumers perceive these types of actions and what effects they have on their attitudes and behaviors. To achieve this, the antecedents that a company must consider before developing an activism initiative in order for it to be supported or valued by their consumers and the resulting effects on corporate reputation and brand equity are analyzed. Likewise, we study whether the political ideology of consumers can moderate these effects.

\subsection{Credibility and authenticity as antecedents of corporate activism}

Although, as mentioned above, corporate activism answers a social demand that provides a favorable context to such actions, companies must also consider other important aspects (antecedents) before undertaking these strategies. The two main conditioning factors are brand and institutional credibility and authenticity, defined as the set of values and beliefs that the organization defends and that makes it unique (identity), which are based on behaviors that are consistent over time.

Credibility is a multidimensional concept that has been defined by various authors such as McCroskey and Teven (1999), who considered that it comprises experience, trust, and goodwill. However, many authors do not consider goodwill to be a factor that builds credibility, but only expertise and trustworthiness (Hovland; Janis; Kelley, 1953; Lafferty, 2007; Newell; Goldsmith, 2001). The latter authors also defined the credibility construct as a set of perceptions that stakeholders have towards a certain source, media, or message.

In the marketing literature, credibility has been widely studied in relation to business organizations because of the importance of knowing whether a company is a source of credibility (Arora, 2007; Lafferty; Goldsmith, 1999) and thus whether its business messages or the media used to disseminate them will have greater persuasive power towards consumers or recipients (Hovland; Janis; Kelley, 1953; Newell; Goldsmith, 2001). However, consumers' perceptions and attitudes regarding business actions depend on whether they have acquired a role as corporate citizens (Matten; Crane, 2005) and the degree of credibility that public institutions have in the eye of the consumer. For this reason, a more specific analysis of the concepts of "corporate credibility" and "institutional credibility" is presented below.

\section{a) Corporate credibility}

One can define "corporate credibility" as the degree to which consumers perceive that a company acts in good faith and possesses the necessary capacity and experience to carry out its business activities (Bigné-Alcaraz; Currás-Pérez; Sánchez-García, 2009). As for the global credibility concept, some authors who work on corporate credibility consider goodwill to be a fundamental dimension regarding the transmission of information about the identity of the company (Jørgensen; Isaksson, 2015; McCroskey; Teven, 1999), while the studies of others do not (Lafferty, 2007; Mahrinasari, 2019; Newell; Goldsmith, 2001; Pérez-Ruiz; Rodríguez-del-Bosque, 2015). Meanwhile, the competence dimension is based on the skills and experience of a company in the field (Lee; Zhang; Abitbol, 2019), while the trust or trustworthiness dimension captures the degree to which a company works with its clients with reliability, consistency (Jørgensen; Isaksson, 2015; Park; Lee; Kim, 2014), and integrity (Arora, 2007).

In empirical studies, corporate credibility has been studied as an antecedent of the attitude towards a brand or purchasing intentions (Goldsmith; Lafferty; Newell, 2000; Lafferty, 2007) as well as perceptions regarding CSR (Bigné-Alcañiz; Chumpitaz-Cáceres; Currás-Pérez, 2010; Erdem; Swait, 2004; Goldsmith; Lafferty; Newell, 2000; Lee; Zhang; Abitbol, 2019; Mahrinasari, 2019; Zasuwa, 2019). On the one hand, it is usual for the results to confirm a positive relationship between corporate credibility and CSR if such responsible business activities are consistent with the competencies of the company and are honestly aimed at its customers (Mahrinasari, 2019). On the other hand, a negative relationship emerges if the company is not credible or there is no business coherence (Aqueveque; Encina, 2010). However, very few empirical studies have treated credibility together with corporate activism, or else their results have not been significant (Parcha; Kingsley-Westerman, 2020), thus more empirical studies are required to confirm whether the trend set by CSR and credibility studies is followed. 
Therefore, since CSR and corporate activism are related concepts and considering the results mentioned above, the first hypothesis is formulated as follows:

H1: The credibility of companies has a positive and significant effect on corporate activism.

\section{b) Institutional credibility}

Institutional credibility can be defined as the degree of trust that citizens have that public institutions will do the right thing, acting for the good of society (Kim; Lee, 2012).

Therefore, it is important to highlight that one of the dimensions of credibility, viz trust, has been questioned in recent years from the consumer's point of view. Events such as the 2008 global economic crisis or cases of political corruption have diminished citizens' trust in public institutions (Pérez-Morote; Pontones-Rosa; Núñez-Chicharro, 2020). In addition, this distrust has increased due to the political polarization manifested by political figures such as Boris Johnson in the United Kingdom or Jair Bolsonaro in Brazil (Korschun; Martin; Vadakkepatt, 2020).

Against this background, consumers expect credible public-sector behavior related to goodwill and trust (Jørgensen; Isaksson, 2014). Furthermore, some authors consider this low institutional credibility to be one of the reasons behind the rapid development of corporate activism (Korschun; Martin; Vadakkepatt, 2020). That is, more than half of consumers already consider that companies can solve social problems better and faster than governments (Edelman, 2019), thus the origins of corporate activism may lie in the current difficulties faced by public institutions to address the most pressing problems in society (Scherer; Palazzo; Matten, 2014).

Although credibility is a concept that has been widely studied in the marketing and communication literature, and previous studies have extensively considered credibility from the point of view of the organization that launches the message (source credibility), the means by which the message is transmitted, and the message itself (Pressgrove; Kim, 2018), no articles that relate institutional credibility to corporate activism or related concepts such as CSR have been found. This is because authors tend to use the concept of trust (credibility dimension) and specifically institutional trust.

However, some articles have proven empirically that low trust in a public institution will result in a positive attitude towards responsible business actions (Rim; Dong, 2018) because consumers consider that companies are more involved in issues of relevance to citizens (Edelman, 2019). The second hypothesis can thus be formulated as follows (H2):

H2. The credibility of institutions has a negative and significant effect on corporate activism.

In addition to the credibility of companies and institutions in the eye of the consumer, another aspect that a company must consider before carrying out a corporate activism initiative is authenticity, that is, ensuring that the position adopted aligns with its corporate identity.

The concept of authenticity has been studied from the point of view of various disciplines (psychology, philosophy, anthropology, sociology, etc.). Grayson and Martinec (2004) referred to this concept as assessments, judgments, or evaluations about how real or genuine something is. The same authors also specifically defined brand authenticity as the perceived consistency of a brand's behavior, in a way that reflects its core norms and values, being true to itself, without undermining its essence or nature and, therefore, involving two types of authenticity (indexical and iconic).

In marketing research, authenticity has also been analyzed from a dual perspective: as an attribute of the object, that is, the authenticity of a brand (Beverland, 2006), or as an attribute of the subject, referring to the authentic emotions of individuals (Hennig-Thurau et al., 2006). However, very few studies are available in the context of corporate activism, although some research links brand authenticity with CSR and conversely CSR authenticity with brand, and thus considers their mutual influence. In this way, Alhouti, Johnson, and Holloway (2016) found that the authenticity of CSR was driven by the impact of the action (i.e., whether it was significant with respect to the size and objectives of the company), the perceived reason, the correction of previous problems for the company, and its fit to the products sold by and the target audience of the company; they also concluded that the authenticity of CSR had a mediating effect on consumer behavior, and thus it had to be not only authentic but also perceived as such. On the other hand, Mohr, Webb, and Harris (2001) also found it necessary to communicate correctly, since the perceived fit between the company and cause influenced the perception regarding the authenticity of the CSR; this means that both companies and brands must be perceived as authentic, so that their authenticity is related and, in turn, could result from CSR initiatives. Likewise, McShane and Cunningham (2012) also found that consumers perceive the motivations for an organization's CSR initiatives as authentic when they play a relevant role both within and outside the CSR environment. This also occurs in the specific case of brand political activism since, from a marketing perspective, companies should only get involved in politics if they can do so in a way that is consistent with the brand and connects authentically with the market (Moorman, 2020).

Consumers and society in general want companies to take sides on sociopolitical issues to drive social change beyond profit-making and transparently communicate their position on these issues 
Regarding the measurement of the perceived authenticity of CSR, Joo, Miller, and Fink (2019) developed a multidimensional scale from the point of view of consumers, comprising seven dimensions: link with the community, reliability, commitment, congruence, benevolence, transparency, and breadth of impact. Some of these dimensions are related to corporate activism: commitment (dedication of the organization to social initiatives rather than other issues (Godfrey, 2005), congruence (fit between the social efforts and business of the company) (Alhouti; Johnson; Holloway, 2016), benevolence (whether the social initiatives are perceived as altruistic and opposed to the search for profit, leading to brand authenticity (Beverland, 2006).

Other studies have analyzed the relationship between brand authenticity and social commitment, an aspect that is directly linked to corporate activism: On the one hand, Ewing, Allen, and Ewing (2012) found that there was a positive effect on brand authenticity when labels guaranteeing an ecological origin were used. In addition, Fritz, Shoenmüeller, and Bruhn (2017) proposed a model that integrated the social commitment of the brand with other variables reviewed in previous studies (inheritance, nostalgia, brand marketing, etc.) and showed that all this had a positive influence on consumer behavior, such that social commitment attributed moral values to the brand, thereby enhancing the perception of its authenticity. Also, Akbar (2016) studied the different dimensions of brand authenticity, including some linked to corporate activism: declared beliefs, beyond those related to money; downplaying business reasons; reliability, that is, credibility and fulfillment of brand promises; and sincerity, in that the brand refuses to compromise its principles and values.

Also in the context of corporate activism and its authenticity, Vredenburg et al. (2020) found that brands can engage with authentic activism by combining their activist messages, purposes, and values with prosocial corporate practice, thus generating greater value for the brand. Furthermore, these authors analyzed the types of activism to determine when a brand was perceived as authentic, revealing that these two types of authenticity, i.e., of the brand and of corporate activism, were related.

On the other hand, authentic brand activism is contrasted with the practice of "woke washing" (Sobande, 2019; Vredenburg et al., 2018), understood as nonauthentic brand activism, since the messages are not aligned with the values, purposes, and corporate practices of the brand, for which it is necessary that four factors (messages, values, purposes, and practices) be combined to construct a holistic system that generates authenticity. Therefore, authenticity is a preliminary issue that companies must consider before engaging in corporate activism as it helps to avoid the skepticism that this type of action can elicit in the public. Authenticity will make the position taken by the company credible, thus resulting in positive effects. Considering the discussion above, hypothesis $\mathrm{H} 3$ can be formulated as follows:

H3. Authenticity has a positive and significant effect on corporate activism.

In summary, if a company has managed to build a solid foundation of corporate credibility and authenticity, it can commit to positions on social issues. Having carried out a corporate activism initiative, it becomes necessary to study its effects on consumers and society in general.

\subsection{Corporate reputation and brand equity as corporate activism outcomes and the moderating role of political ideology}

Korschun, Martin, and Vadakkepatt (2020) called for research and highlighted the need for more studies to analyze the outcomes (such as company performance, brand equity, reputation, or purchasing intentions) that can be derived from corporate activism. Our study focuses on two of these: corporate reputation and brand equity. It also analyzes the moderating effect of the political ideology of consumers on this relationship.

Corporate reputation is the mental representation of a company in the mind of its stakeholders that is built in an aggregate way over time and depends on the ability to satisfy their expectations (Fombrun; Shanley, 1990; Fombrun, 1996).

For several decades, this concept has attracted interest from academics and professionals since a positive relationship has been demonstrated between reputation and the attitudes and behaviors of stakeholders (clients, employees, investors, etc.) towards a company (Dowling, 2016; Fombrun; Rindova, 1996; Ponzi; Fombrun; Gardberg, 2011). Corporate reputation also has a positive effect on other important outcomes, such as consumer loyalty (Bartikowski; Walsh; Beatty, 2011) and financial performance (De-la-Fuente-Sabaté; De-Quevedo-Puente, 2003; Eberl; Schwaiger, 2005; Fombrun; Van-Riel, 2004; Gatzert, 2015; Roberts; Dowling, 2002).

No works have studied the effect of corporate activism on reputation, although some have considered the effect on reputation of CSR, a concept different from corporate activism (as it is linked to business activities and such issues result, in most cases, from dialog with stakeholders, avoiding controversial or polemical issues), although it shares some characteristics (since both are carried out on a voluntary basis and seek to contribute to social improvement). For Sarkar and Kotler (2018), corporate activism is an evolution of CSR.

From the perspective of CSR, reputation is considered to be one of the main effects of CSR (Agarwal; Osiyevskyy; Feldman, 2015; Aguilera-Caracuel; Guerrero-Villegas, 2018; Odriozola; Baraibar-Díez, 2017; Rothenhoefer, 2019), especially when carried out in a proactive way (Martín-de-Castro; Navas-López; López-Sáez, 2006) and if there is a fit between 
the social and environmental commitments adopted by the company and its activity (Brammer; Pavelin, 2006). In addition, some studies have analyzed how the relationship between CSR and reputation has a positive effect on financial performance (Saeidi et al., 2015; Van-Beurden; Gössling, 2008; Waddock; Graves, 1997), consumer perceptions of product quality (Sen; Bhattacharya, 2001), organizational brand equity (Lai et al., 2010), and attracting talent (Turban; Cable, 2003).

Considering that CSR promotes a favorable relationship between the company and its interest groups (Ponzi; Fombrun; Gardberg, 2011), it seems clear that it will also have a positive impact on reputation. In this research, we understand that this statement can be transferred to corporate activism or related concepts such as corporate social advocacy (CSA) or corporate political advocacy (CPA), since they are related to CSR (Wilcox, 2019) and the related strategies must be coordinated (Den-Hond et al., 2014).

However, although the concepts of CSR and corporate activism have become very important in recent decades, the impact of activism or CPA on reputation has been less well studied than that of CSR. Most research has focused on stakeholder activism or social activism (surveillance or boycotts of companies when stakeholders do not agree with corporate actions) and the negative impact of these actions on reputation (Abito; Besanko; Diermeier, 2019; Hoffmann; Brønn; Fieseler, 2016; King, 2008; McDonnell; King, 2013).

However, more studies are needed to analyze the impact on reputation of the political and social positions adopted by companies and which aspects organizations should consider when choosing and communicating topics to achieve a positive effect.

Korschun, Martin, and Vadakkepatt (2020) propose a framework for understanding marketing and political activity and identify that reputation is one of the corporate outcomes that derives from these actions. For Wilcox (2019), corporate activism can have a positive impact on reputation and loyalty as more and more clients demand that companies express their values and become involved in social and political issues, although it can also have a negative effect on those parts of the public that do not share those beliefs or political positions, thus companies must identify relevant issues that are related to their values.

In addition to reputation, another widely studied effect in the marketing and communication literature is brand equity (Keller, 1998; Pappu; Quester; Cooksey, 2005) because it creates value for both the company and the consumer (Aaker, 1991). Brand equity is

"a set of brand assets and liabilities linked to a brand, its name and symbol, that add to or subtract from the value provided by a product or service to a firm and/or to that firm's customers" (Aaker, 1991, p. 15).

As pointed out by Keller and Lehmann (2006), brand equity has been studied from different perspectives, including (1) the company, (2) finances, and (3) the customer. In this paper, we understand brand equity from the consumer perspective and analyze the effect of corporate activism initiatives on brand equity.

Given the novelty of corporate activism, few studies have linked corporate activism and brand equity (Vredenburg et al., 2020; Corcoran; Newman; Devasagayam, 2016). However, we found several studies that indicate a positive effect of CSR on brand equity (for both consumers and other audiences) from different focuses that can be applied to corporate activism actions.

Bhattacharya (2017) analyzed this relationship and concluded that CSR contributes significantly to social transformation along with building the social identity of brands by generating brand-social linkages and consumer engagement for higher brand equity.

Fatma, Rahman, and Khan (2015) studied the effect of CSR initiatives on corporate reputation and brand equity. Their findings show how CSR actions have a positive impact on brand equity if they are based on trust as a mediator. Torres et al. (2012) also found a positive relationship and highlight the importance for global brand strategies of combining global strategies and causes with actions that satisfy the interests of customers in local communities.

Considering previous studies and given that there is an increasing demand from consumers for companies to adopt a position on political and social issues, corporate activism can both be valued by consumers and influence brand equity (Corcoran; Newman; Devasagayam, 2016; Korschun; Martin; Vadakkepatt, 2020; Vredenburg et al., 2020). Meanwhile, consumers are increasingly skeptical and critical of brands and suspicious of the motives behind such campaigns (Du; Bhattacharya; Sen, 2010; Holt, 2002), which can reduce their effects and even provoke rejection. Recent studies (Moorman, 2020; Sarkar; Kotler, 2018) have pointed out the importance of authenticity for brand activism to be credible and effective. Vredenburg et al. (2020) highlighted the importance of ensuring that the consumer perceives the motives behind a corporate activism initiative as authentic, so that it can have a positive effect on brand equity and also achieve social change. On the other hand, Corcoran, Newman, and Devasagayam (2016) studied whether corporate activism affects consumer purchasing attitudes and concluded that companies should become involved in corporate activism and make these campaigns known to the majority of the public in order to increase their brand equity. 
Therefore, demonstrating a real commitment to a cause or the motives behind an action transcend the business itself, being aspects that minimize public skepticism and contribute to the creation of brand equity.

Bearing the above in mind, CSR and corporate activism are aspects that stakeholders consider when evaluating a company and, therefore, affect both corporate reputation and brand equity. However, this effect may be moderated by various factors such as consumer values and political ideology (Jost; Langer; Singh, 2017; Korschun; Martin; Vadakkepatt, 2020; Rim; Lee; Yoo, 2020).

Jost (2006, p. 653) defines political ideology as

"an interrelated set of moral and political attitudes that possesses cognitive, affective, and motivational components."

Political ideology is related to our values and beliefs and directly influences people's attitudes, opinions, and behaviors. However, little study has been done of how political ideology influences consumer behavior (Jung et al., 2017). The support for social, political, and environmental issues by companies in an increasingly polarized society (lyengar; Westwood, 2015; Jost, 2006; Reiljan, 2020) suggests that divergent reactions may be produced in consumer behaviors. Mukherjee and Alhuizen (2020) raise the need for empirical studies that analyze whether and how political ideology moderates the effect of corporate activism.

Although, as pointed out by these authors, we do not find research that relates political ideology and corporate activism from the consumer's point of view, we do find recent works in the communication and marketing field that study the influence of consumers' political ideology (Jung et al., 2017; Kim; Park; Dobois, 2018; Ordabayeva; Fernandes, 2018; Ulver; Laurell, 2020; Valera-Ordaz; Doménech-Beltrán, 2020). In these works, the distinction between conservatism and liberalism is the classification most frequently used when talking about political ideology (Graham; Haidt; Nosek, 2009; Ordabayeva; Fernandes, 2018).

The work of Paek and Nelson (2009) indicates that those consumers with a liberal ideology have a greater tendency to take part in boycotting and buycotting. Fernandes and Mandel (2014) studied how political ideology can affect consumption choices and conclude that conservatives are more prone to variety seeking. Ordabayeba and Fernandes (2018) analyzed how political ideology influences the way consumers differentiate themselves, thus conservatives seek vertical differentiation (choosing products that show them as better than others) while liberals seek horizontal differentiation (choosing products that show that are unique or different from others). Chan and Palmeira (2021) analyzed the moderating role of political ideology in consumer responses to brand crisis apologies and concluded that they have a greater influence and are more credible for liberals than for conservatives. The latter authors doubt that a company will really change, even after an apology.

In general, investigations carried out to date coincide in highlighting various features that distinguish conservatives and liberals. Thus, conservatives have been shown to embrace structure, stability, conscientiousness, and responsibility, while liberals are more open to change, tolerant, and drawn to novelty and diversity (Carney et al., 2008). Conservatives tend to engage in the justification of social systems (Jost; Hunyady, 2003), which translates, for example, into such consumers' reporting less complaints and also being less likely than liberal consumers to dispute complaint resolutions (Jung et al., 2017). For Jost et al. (2003), stakeholders with different ideologies usually adopt opposing positions on sociopolitical issues. As pointed out by those authors, liberals, unlike conservatives, give greater prominence to protecting the environment or defending civil rights or issues such as social justice, diversity, or social change.

Considering the discussion above, although no studies have specifically analyzed the relationship between corporate activism and reputation and brand equity with political ideology as a moderating variable, we hypothesize that:

H4a. For liberals, corporate activism has a positive and significant effect on corporate reputation.

H4b. For conservatives, corporate activism has a nonsignificant effect on corporate reputation.

H5a. For liberals, corporate activism has a positive and significant effect on brand equity.

H5b. For conservatives, corporate activism has a nonsignificant effect on brand equity.

Considering the discussion above, our hypotheses can be summarized as follows: The credibility of companies (H1) and authenticity $(\mathrm{H} 3)$ have a positive and significant effect on corporate activism, whereas the credibility of institutions ( $\mathrm{H} 2$ ) has a negative and significant effect on corporate activism. Regarding political ideology as a moderator of the effects of corporate activism on reputation and brand equity, we hypothesize that, for liberals, corporate activism has a positive and significant effect on corporate reputation ( $\mathrm{H} 4 \mathrm{a}$ ) and on brand equity ( $\mathrm{H} 5 \mathrm{a}$ ), whereas for conservatives, corporate activism has a nonsignificant effect on corporate reputation or brand equity (H5b). Therefore, the conceptual model proposed, derived from the literature review, is shown in Figure 1.

We test our hypotheses with a sample of 1,521 individuals. The next section details our sampling and data collection procedures and measurement scales. 


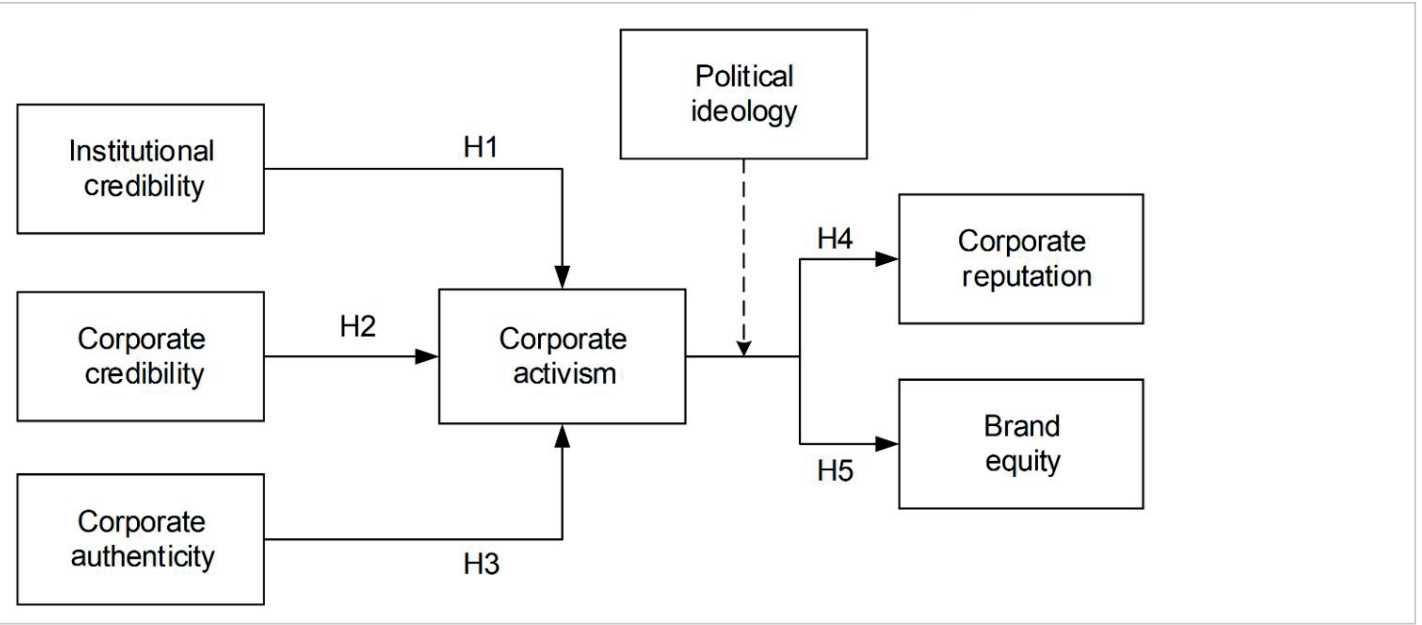

Figure 1. Conceptual model

\section{Methodology}

\subsection{Sampling and data collection}

To test the hypotheses, a sample of 1,521 individuals was used, selected by random stratified sampling of the entire Spanish population aged over 18 years. The sampling error is thus $2.51 \%$ for $p=q=0.5$ with a $95 \%$ confidence interval. This sample was extracted from an online panel made up of individuals selected to fit the sociodemographic characteristics of the Spanish population (CIS, 2021), managed by a specialized research company, and was conducted between 20 October and 2 November $2020^{1}$.

Participants receive personal invitations, thus reducing the risk of self-selection and possible duplication. The panelist response rate was 47\%, and the entire process followed ISO standard 20252.

The strata were selected based on geographic (province), age, and gender criteria, and participants received compensation in the form of points exchangeable for gifts, once the survey was completed to prevent their use to purchase products that could be related to the object of study. This avoids biases derived from obtaining rewards that could

Table 1. Descriptive analysis of the sample

\begin{tabular}{|c|c|c|}
\hline & Frequency & Percentage \\
\hline \multicolumn{3}{|c|}{ Age (years) } \\
\hline $18-24$ & 186 & 12.23 \\
\hline $24-34$ & 231 & 15.19 \\
\hline $35-44$ & 340 & 22.35 \\
\hline $45-54$ & 308 & 20.25 \\
\hline $55-64$ & 259 & 17.03 \\
\hline$>64$ & 197 & 12.95 \\
\hline Sum & 1,521 & 100 \\
\hline \multicolumn{3}{|l|}{ Gender } \\
\hline Male & 753 & 49.51 \\
\hline Female & 768 & 50.49 \\
\hline Sum & 1,521 & 100 \\
\hline
\end{tabular}

distort the perception of a brand and/or a certain category of products. The profile of the participants in the sample is summarized in Table 1.

Data collection was carried out through a structured questionnaire that contained the necessary scales to test the hypotheses. All items were evaluated using a five-point Likert scale ranging from "totally disagree" to "totally agree," inversely coded where necessary.

The data extracted from the questionnaire were analyzed using structural equation modeling (SEM), so that the constructs of interest could be inferred and related to each other. The other methodological alternative that can be used in these cases is partial least squares (PLS) modeling, which is more predictive and less oriented toward the contrast of theoretical assumptions.

\subsection{Measurement scales}

The constructs of "credibility of institutions" and "credibility of corporations" were constructed from the scale of McCroskey and Teven (1999), that of "corporate authenticity" using the scale of Moulard, Raggio, and Folse (2016), "corporate reputation" from the scale of Ponzi, Fombrun, and Gardberg (2011), and "brand equity" using the scale of Pappu, Quester, and Cooksey (2005), which in turn comprises the scales of Aaker (1991; 1996), Yoo, Donthu, and Lee (2000), and Yoo and Donthu (2001).

To the best of the authors' knowledge, no validated scales exist to measure corporate activism, thus a battery was designed using 20 items extracted from some related scales (Austin; Gaither; Gaither, 2019; Borden, 2019) and the annual report by Edelman (2019) on trust in businesses. From this initial battery of items, and by means of a confirmatory factorial analysis (CFA), a scale made up of three differentiated constructs was extracted: "social activism," "declarative political activism," and "reactionary political activism." "Social activism" refers to the involvement of a company in activist initiatives that promote social causes, being defined by three items: 
(i) "Large corporations should work to improve society,"

(ii) "Large corporations should advocate for social issues, even when there is not a clear social consensus," and

(iii) "Large companies have an ethical obligation to push for social change." "Declarative political activism" involves the adoption of clear public positions on political ideology by some large corporations.

This construct is made up of the following items:

(i) "Large corporations should take a political stand,"

(ii) "Large corporations should get involved in politics," and

(iii) "Large corporations have an obligation to publicly express their policy preferences."

Finally, the construct "reactionary political activism" is defined as the set of initiatives that a company can adopt to address the lack of competence of governments and public institutions. This factor comprises the following items:

(i) "When the government doesn't or won't try to fix a problem, large corporations should fix it themselves,"

(ii) "When the government tries to pass a bad law or unethical regulation, large corporations should try to stop them," and

(iii) "Large corporations should take action against bad government or politicians."

The results of the CFA indicate significant factor loadings of all items with their respective factor, with Cronbach's alpha greater than 0.7 in all cases, having adjustment indicators within the limits considered to be good or very good (GFI = 0.97; $\mathrm{AGFI}=0.94 ; \mathrm{CFI}=0.96 ; \mathrm{TLI}=0.95 ; \mathrm{RMSEA}=0.06)$. Finally, political ideology was collected using an ordinal scale that identified all the response options of the political spectrum $(C I S, 2021)$.

Table 2 presents a summary of the measures used for each construct and the origin of each of them.

Table 2. Measurement scales

\begin{tabular}{|c|c|c|}
\hline Scale & Construct & Authors \\
\hline Institutional credibility & $\begin{array}{l}\text { Competence } \\
\text { Goodwill } \\
\text { Trustworthy }\end{array}$ & McCroskey and Teven (1999) \\
\hline Corporate credibility & $\begin{array}{l}\text { Competence } \\
\text { Goodwill } \\
\text { Trustworthy }\end{array}$ & McCroskey and Teven (1999) \\
\hline Authenticity & Authenticity & Moulard; Raggio; Folse (2016) \\
\hline Corporate activism & $\begin{array}{l}\text { Corporate social activism } \\
\text { Corporate political activism } \\
\text { Corporate reactionary activism }\end{array}$ & $\begin{array}{l}\text { This paper, based on Austin; Gaither; Gaither (2019); Borden } \\
\text { (2019), Edelman (2019) }\end{array}$ \\
\hline Corporate reputation & Corporate reputation & Ponzi; Fombrun; Gardberg (2011) \\
\hline Brand equity & $\begin{array}{l}\text { Quality } \\
\text { Brand associations } \\
\text { Loyalty } \\
\text { Awareness } \\
\text { Organizational associations }\end{array}$ & $\begin{array}{l}\text { Pappu; Quester; Cooksey (2005), } \\
\text { Aaker (1991; 1996), } \\
\text { Yoo; Donthu; Lee (2000), } \\
\text { Yoo and Donthu (2001) }\end{array}$ \\
\hline Political ideology & Political ideology & CIS (2021) \\
\hline
\end{tabular}

\section{Results}

\subsection{Estimation of the measurement model}

The model was estimated by analyzing the reliability and validity of the measurement model, to enable an estimation of the structural model and test the hypotheses. In all cases, Cronbach's alpha was higher than the established standard limits, and in the composite reliability analysis, none of the calculated indicators was below 0.7 , so it can be stated that there are no reliability problems in the estimates (Hair et al., 2006). The calculated mean variance extracted (AVE) values are above 0.5 , so the model does not present convergent validity problems either. In addition, all the factorial loads of the measurement model are significant and above 0.5 (see Table 3).

Table 3. Factor loadings

\begin{tabular}{|c|c|c|}
\hline Latent variables and items & $\begin{array}{c}\text { Factor } \\
\text { loading }\end{array}$ & $\begin{array}{c}\text { Std. error } \\
\boldsymbol{p} \text {-Value }\end{array}$ \\
\hline Credibility in institutions & \\
\hline Competence & 0.781 & 0.026 \\
\hline State institutions act intelligently & $<0.001$ \\
\hline State institutions are made up of well-trained personnel & 0.896 & 0.024 \\
\hline State institutions are made up of experts & $<0.001$ & 0.853 \\
\hline
\end{tabular}




\begin{tabular}{|c|c|c|c|}
\hline Latent variables and items & $\begin{array}{l}\text { Factor } \\
\text { loading }\end{array}$ & Std. error & $p$-Value \\
\hline State institutions have well-informed staff & 0.824 & 0.027 & $<0.001$ \\
\hline State institutions are made up of competent and capable personnel & 0.781 & 0.026 & $<0.001$ \\
\hline State institutions are brilliantly managed & 0.898 & & $<0.001$ \\
\hline \multicolumn{4}{|l|}{ Goodwill } \\
\hline State institutions take care of citizens & 0.902 & 0.029 & $<0.001$ \\
\hline State institutions have the citizen as the center of their interests & 0.752 & 0.035 & $<0.001$ \\
\hline State institutions care about citizens & 0.901 & 0.030 & $<0.001$ \\
\hline State institutions care and understand social problems & 0.857 & & $<0.001$ \\
\hline \multicolumn{4}{|l|}{ Trustworthy } \\
\hline State institutions are honest & 0.898 & 0.034 & $<0.001$ \\
\hline State institutions are trustworthy & 0.901 & 0.035 & $<0.001$ \\
\hline State institutions are respectable & 0.850 & 0.038 & $<0.001$ \\
\hline State institutions act with moral principles & 0.879 & 0.035 & $<0.001$ \\
\hline State institutions are ethical and responsible & 0.922 & 0.034 & $<0.001$ \\
\hline State institutions are authentic and genuine & 0.803 & & $<0.001$ \\
\hline \multicolumn{4}{|l|}{ Credibility in corporations } \\
\hline \multicolumn{4}{|l|}{ Competence } \\
\hline Large companies act intelligently & 0.671 & 0.036 & $<0.001$ \\
\hline Large companies are made up of well-trained staff & 0.868 & 0.029 & $<0.001$ \\
\hline Large companies are made up of experts & 0.850 & 0.030 & $<0.001$ \\
\hline Large companies have well-informed staff & 0.820 & 0.030 & $<0.001$ \\
\hline Large companies are made up of competent and capable personnel & 0.865 & & $<0.001$ \\
\hline Large companies are brilliantly managed & 0.679 & 0.035 & $<0.001$ \\
\hline \multicolumn{4}{|l|}{ Goodwill } \\
\hline Large companies take care of citizens & 0.898 & 0.028 & $<0.001$ \\
\hline Large companies have the citizen as their core interest & 0.666 & 0.042 & $<0.001$ \\
\hline Large companies care about citizens & 0.898 & 0.028 & $<0.001$ \\
\hline Large companies care and understand social issues & 0.849 & & $<0.001$ \\
\hline \multicolumn{4}{|l|}{ Trustworthy } \\
\hline Large companies are honest & 0.828 & 0.044 & $<0.001$ \\
\hline Large companies are trustworthy & 0.764 & 0.044 & $<0.001$ \\
\hline Large companies are respectable & 0.783 & 0.045 & $<0.001$ \\
\hline Large companies act with moral principles & 0.750 & 0.045 & $<0.001$ \\
\hline Large companies are ethical and accountable & 0.811 & 0.046 & $<0.001$ \\
\hline Great companies are authentic and genuine & 0.730 & & $<0.001$ \\
\hline \multicolumn{4}{|l|}{ Authenticity } \\
\hline Large companies have true passion for what they do & 0.809 & 0.033 & $<0.001$ \\
\hline Large companies want to do their best when they offer their products or services & 0.839 & 0.035 & $<0.001$ \\
\hline Large companies carry out their work with devotion and dedication & 0.859 & & $<0.001$ \\
\hline \multicolumn{4}{|l|}{ Corporate activism } \\
\hline \multicolumn{4}{|l|}{ Corporate social activism } \\
\hline Large companies should defend social positions & 0.671 & 0.060 & $<0.001$ \\
\hline Large companies have an ethical obligation to promote social change & 0.785 & 0.063 & $<0.001$ \\
\hline Large companies and governments should participate equally in solving social problems & 0.725 & & $<0.001$ \\
\hline \multicolumn{4}{|l|}{ Corporate political activism } \\
\hline I believe that large companies should position themselves politically & 0.848 & 0.061 & $<0.001$ \\
\hline Large companies should get involved in politics & 0.805 & 0.057 & $<0.001$ \\
\hline CEOs of major companies have an obligation to express publicly their political preferences. & 0.677 & & $<0.001$ \\
\hline \multicolumn{4}{|l|}{ Corporate reactionary activism } \\
\hline When the government tries to pass an unfair or little ethical law, big business should try to stop it & 0.736 & 0.056 & $<0.001$ \\
\hline
\end{tabular}




\begin{tabular}{|c|c|c|c|}
\hline Latent variables and items & $\begin{array}{l}\text { Factor } \\
\text { loading }\end{array}$ & Std. error & $p$-Value \\
\hline Large companies should take initiatives against bad governments or bad politicians & 0.703 & 0.057 & $<0.001$ \\
\hline $\begin{array}{l}\text { When the government does not solve citizens' problems, large companies should take the } \\
\text { initiative }\end{array}$ & 0.728 & & $<0.001$ \\
\hline \multicolumn{4}{|l|}{ Corporate reputation } \\
\hline Large companies make me feel good & 0.853 & 0.026 & $<0.001$ \\
\hline I admire and respect large companies & 0.867 & 0.028 & $<0.001$ \\
\hline In general, large companies have a good reputation & 0.682 & 0.030 & $<0.001$ \\
\hline I trust large companies & 0.881 & & $<0.001$ \\
\hline \multicolumn{4}{|l|}{ Brand equity } \\
\hline \multicolumn{4}{|l|}{ Quality } \\
\hline Large companies offer good quality products & 0.853 & & $<0.001$ \\
\hline The quality of large companies' products is always good & 0.801 & 0.033 & $<0.001$ \\
\hline Large companies offer durable products & 0.768 & 0.033 & $<0.001$ \\
\hline Large companies offer products with excellent features & 0.840 & 0.030 & $<0.001$ \\
\hline \multicolumn{4}{|l|}{ Brand associations } \\
\hline Large companies offer superior quality products & 0.817 & 0.033 & $<0.001$ \\
\hline Large companies offer reliable products & 0.847 & & $<0.001$ \\
\hline \multicolumn{4}{|l|}{ Loyalty } \\
\hline I consider myself faithful to large companies' brands & 0.875 & 0.037 & $<0.001$ \\
\hline Large company brands are my first purchase option & 0.813 & & $<0.001$ \\
\hline \multicolumn{4}{|l|}{ Awareness } \\
\hline I can easily remember the names of most large companies & 0.836 & 0.063 & $<0.001$ \\
\hline I remember almost every large company's brands I have ever bought & 0.750 & 0.065 & $<0.001$ \\
\hline When someone mentions a leading company, I recognize it with no trouble. & 0.708 & & $<0.001$ \\
\hline \multicolumn{4}{|l|}{ Organizational associations } \\
\hline I like large companies & 0.830 & 0.059 & $<0.001$ \\
\hline I trust large companies' brands & 0.849 & 0.054 & $<0.001$ \\
\hline I like to brag about buying products from large companies & 0.630 & & $<0.001$ \\
\hline
\end{tabular}

\subsection{Estimation of the structural model}

The fit indices for the global model lie within the acceptable range and thus do not present adequacy problems (GFI = $0.87 ; \mathrm{AGFI}=0.85 ; \mathrm{CFI}=0.94 ; \mathrm{TLI}=0.93 ; \mathrm{RMSEA}=0.04)$. Discriminant validity was evaluated using the matrix formed by the square root of the mean variance extracted on the diagonal, and the correlations between constructs off the diagonal. In all cases, the square root of AVE was greater than the observed correlations. Regarding the model estimated with political ideology as a moderating variable, the adjustment indices are similar (GFI $=0.80 ; \mathrm{AGFI}=0.77 ; \mathrm{CFI}=0.92 ; \mathrm{TLI}=$ 0.92; RMSEA $=0.03$ ).

Hypothesis testing showed that all the coefficients had the expected sign, consistent with the theory (Table 4).

Table 4. Hypothesis testing

\begin{tabular}{|c|c|c|c|c|c|c|}
\hline \multicolumn{2}{|c|}{ Hypothesis } & \multirow[b]{2}{*}{$\rightarrow$} & \multirow[b]{2}{*}{ Corp. activism } & \multirow{2}{*}{$\begin{array}{c}\text { Estimate (Std.) } \\
0.707\end{array}$} & \multirow{2}{*}{$\begin{array}{c}\text { Std. error } \\
0.032\end{array}$} & \multirow{2}{*}{$\begin{array}{c}\text { Critical ratio } \\
5.910^{* * *}\end{array}$} \\
\hline $\mathrm{H} 1$ & Corporate credibility & & & & & \\
\hline $\mathrm{H} 2$ & Institutional credibility & $\rightarrow$ & Corp. activism & -0.062 & 0.005 & $-3.017^{* * *}$ \\
\hline H3 & Authenticity & $\rightarrow$ & Corp. activism & 0.275 & 0.013 & $5.046^{* * *}$ \\
\hline \multicolumn{7}{|c|}{ Liberals } \\
\hline $\mathrm{H} 4 \mathrm{a}$ & Corp. activism & $\rightarrow$ & Corp. reputation & 1.008 & 0.690 & $6.135^{* * *}$ \\
\hline $\mathrm{H} 5 \mathrm{a}$ & Corp. activism & $\rightarrow$ & Brand equity & 0.895 & 0.476 & $5.998^{* * *}$ \\
\hline \multicolumn{7}{|c|}{ Conservatives } \\
\hline $\mathrm{H} 4 \mathrm{~b}$ & Corp. activism & $\rightarrow$ & Corp. reputation & 0.988 & 4.075 & 1.653 \\
\hline $\mathrm{H} 5 \mathrm{~b}$ & Corp. activism & $\rightarrow$ & Brand equity & 0.776 & 3.155 & 1.648 \\
\hline
\end{tabular}


The results reveal that institutional credibility, corporate credibility, and authenticity are antecedents of corporate activism and, therefore, explain which circumstances contribute to the implementation of this type of initiative. According to the parameters obtained, when credibility in institutions decreases, individuals perceive that corporations should be more directly involved in matters of a social and political nature, even those that are controversial or cause polarization in society.
The results reveal that institutional credibility, corporate credibility and authenticity are antecedents of corporate activism and, therefore, explain which circumstances contribute to the implementation of this type of initiative

However, the relationship between corporate activism and reputation and brand equity changes when political ideology is incorporated as a moderating variable. In this sense, it is interesting to observe how individuals with a more conservative ideology do not perceive possible positive effects on reputation or brand equity from this type of practice related to corporate activism. In contrast, individuals with a more liberal ideological tendency do perceive that the involvement of companies in activist initiatives has a positive impact on their reputation and brand equity. For this group, the responsibility of organizations seems to go beyond their corporate function, to engage in practices related to social and political aspects that transcend the traditional limits of their managerial or commercial function, and ideologically position themselves by taking sides on controversial or polarizing issues.

Table 5 presents a summary of the hypotheses raised and the results of the testing based on the structural equation model.

Table 5. Summary of hypothesis testing

\begin{tabular}{|c|l|c|}
\hline Hypothesis & \multicolumn{1}{c|}{ Content } & Verification \\
\hline H1 & The credibility of companies has a positive and significant effect on corporate activism. & Accepted \\
\hline H2 & The credibility of institutions has a negative and significant effect on corporate activism. & Accepted \\
\hline H3 & Authenticity has a positive and significant effect on corporate activism. & Accepted \\
\hline H4a & For individuals with a liberal ideology, corporate activism has a positive and significant effect on corporate reputation. & Accepted \\
\hline H4b & For individuals with a conservative ideology, corporate activism has nonsignificant effect on corporate reputation. & Accepted \\
\hline H5a & For individuals with a liberal ideology, corporate activism has a positive and significant effect on brand equity. & Accepted \\
\hline H5b & For individuals with a conservative ideology, corporate activism has a nonsignificant effect on brand equity. & Accepted \\
\hline
\end{tabular}

\section{Discussion and conclusions}

The results obtained in this work confirm the importance of corporate and institutional credibility, as well as authenticity, as antecedents of corporate activism. The confirmation that all these variables have a positive effect on the assimilation of corporate activism by the consumer is of great interest and is especially relevant to verify that lower institutional credibility leads to greater support for business initiatives related to corporate activism. Likewise, the results on the effects of this phenomenon are of great importance, since the influence of corporate activism on the reputation and brand equity of a company is clear. The finding that political ideology (conservative or liberal tendency) can act as a moderator of these effects is of particular value.

These results contribute to this academic field in the following ways: first, studies on corporate credibility have focused more deeply on its relationship with CSR, whether positive, when business activities are consistent with the competencies of the company (Mahrinasari, 2019), or negative if there is no such coherence (Aqueveque; Encina, 2010). On the other hand, low institutional credibility has been studied by authors who consider that it is one of the explanations for the rapid development of corporate activism (Korschun; Martin; Vadakkepatt, 2020), although no specific studies directly relate it to this phenomenon. In addition, authenticity has been related to how real or genuine something is (Grayson; Martinec, 2004), although there are no specific works on its relationship with corporate activism. However, the connection of this phenomenon with CSR has been studied (Alhouti; Johnson; Holloway, 2016; Mohr; Webb; Harris, 2001). Therefore, this work represents an advance in the study of these concepts as antecedents for the implementation of corporate activism initiatives.

On the other hand, previous literature reveals that a company's stance on political or social issues may have a positive effect on its reputation and brand equity, although such communications must be consistent and supported by corporate actions (Vredenburg et al., 2020) that result in social change. In this sense, the current work confirms that corporate activism has effects on reputation and brand equity.

In addition, some studies have confirmed the importance of the consumer's political ideology as a moderating effect (Jost; Langer; Singh, 2017), although how political ideology influences consumer behavior has not yet been studied in depth (Jung et al., 2017), revealing the spe-
The relationship between corporate activism and reputation and brand equity changes when political ideology is incorporated as a moderating variable 
cific need for empirical studies that analyze the specific effect it may have on corporate activism (Mukherjee; Alhuizen, 2020). However, some studies have already shown that there are differentiating features between conservatives and liberals (Carney et al., 2008; Jung et al., 2017), although no research has specifically analyzed the influence that political ideology can have on reputation or brand equity. This study delves into this aspect, specifically advancing knowledge on its effect as a variable moderating the effects of corporate activism on such reputation and brand equity.

Moreover, the results of this work also have practical implications since they could be very useful for companies and managers who wish to introduce corporate activism into their companies as a marketing strategy. Taking a stand on polarizing or controversial issues involves corporate strategic decision-making such as brand management, brand positioning, product launches or modifications, public relations, or advertising campaigns (Pintado-Blanco; Sánchez-Herrera; López-Aza, 2020).

In this regard, the current results are of interest to enable proper selection of the specific issues, whether political or social, that a company could support, in addition to their effective communication to achieve positive effects on the audience, as long as companies align their activist message with their purpose, values, and activist practices. However, companies should avoid being considered as "woke-washing" because this might affect their corporate credibility. Such organizations are involved in inauthentic brand activism (Vredenburg et al., 2020) only based on trends or practices that may not clearly align with their message.

Thus, companies should consider corporate and institutional credibility as antecedents that can affect the perception of corporate activism by consumers, particularly at times when the credibility of institutions may be lower, since this implies a better perception of activist actions. Likewise, the effects of corporate activism on corporate reputation and brand equity should also be considered, especially in cases where the political ideology of consumers can be seen as moderating these effects. In this sense, companies should make a greater effort to understand the ideology of their audiences before communicating their support for social or political issues and thus carry out authentic corporate activism practices.

The current work suffers from some limitations. On the one hand, one could delve into the attitude of consumers, based on their political ideology, towards the issues defended by a company to specify the results and obtain more conclusive information on this issue. In addition, the results may differ depending on the sociodemographic characteristics of the consumers such as age, gender, education, or country of origin. Also, other variables such as culture, corporate identity, or company purpose could moderate the effects obtained on reputation and brand equity.

Likewise, the application of the results obtained may differ depending on the sector in which the companies are active, as well as their historical trajectory in relation to the treatment and support of other related issues, such as CSR. Besides, it would be interesting to analyze whether the current results vary according to the type of activism (political or social), given that the current work was carried out using both types together. Finally, it would be relevant to analyze the perceptions of other stakeholders such as employees or investors, given their importance in the company.

In summary, multiple factors of interest for the development of corporate activism can be analyzed in the future. It is foreseeable that this phenomenon will garner greater importance in organizations, indicating the importance of learning more about its implications for companies and their consumers.
The support for social, political, and environmental issues by companies in an increasingly polarized society suggests that divergent reactions may be produced in consumer behaviors

\section{Note}

1. Sociodemographic characteristics of the Spanish population are based on Centro de Investigaciones Sociológicas (CIS) research (barometers, social and political surveys), and other public sources (i.e., INE).

\section{References}

Aaker, David A. (1991). Managing brand equity. San Francisco: The Free Press. ISBN: 0029001013

Aaker, David A. (1996). "Measuring brand equity across products and markets". California management review, v. 38, n. 3, pp. 102-120.

Abito, José-Miguel; Besanko, David; Diermeier, Daniel (2019). Corporate reputation and social activism: Strategic interaction, firm behavior, and social welfare. Oxford University Press. ISBN: 9780199386154 https://doi.org/10.1093/oso/9780199386154.001.0001

Agarwal, James; Osiyevskyy, Oleksiy; Feldman, Percy M. (2015). “Corporate reputation measurement: Alternative factor structures, nomological validity, and organizational outcomes". Journal of business ethics, v. 130, n. 2, pp. 485-506. https://doi.org/10.1007/s10551-014-2232-6 
Aguilera-Caracuel, Javier; Guerrero-Villegas, Jaime (2018). “How corporate social responsibility helps MNEs to improve their reputation. The moderating effects of geographical diversification and operating in developing regions". Corporate social responsibility and environmental management, v. 25, n. 4, pp. 355-372.

https://doi.org/10.1002/csr.1465

Aqueveque, Claudio; Encina, Catherine (2010). “Corporate behavior, social cynicism, and their effect on individuals' perceptions of the company". Journal of business ethics, v. 91, pp. 311-324.

https://doi.org/10.1007/s10551-010-0621-z

Akbar, Moustapha (2016). Reconceptualizing brand authenticity and validating its scale. Doctoral dissertation. Lethbridge, Alta: University of Lethbridge, Faculty of Management.

Alhouti, Sarah; Johnson, Catherine M.; Holloway, Betsy-Bugg (2016). “Corporate social responsibility authenticity: Investigating its antecedents and outcomes". Journal of business research, v. 69, n. 3, pp. 1242-1249.

https://doi.org/10.1016/j.jbusres.2015.09.007

Arora, Raj (2007). "Message framing strategies for new and mature products". Journal of product \& brand management, v. 16, n. 6 , pp. 377-385.

https://doi.org/10.1108/10610420710823744

Austin, Lucinda; Gaither, Barbara; Gaither, T. Kenn (2019). “Corporate social advocacy as public interest communications: Exploring perceptions of corporate involvement in controversial social-political issues". Journal of public interest communications, v. 3, n. 2.

https://doi.org/10.32473/jpic.v3.i2.p3

Bartikowski, Boris; Walsh, Gianfranco; Beatty, Sharon E. (2011). "Culture and age as moderators in the corporate reputation and loyalty relationship". Journal of business research, v. 64, n. 9, pp. 966-972.

https://doi.org/10.1016/j.jbusres.2010.11.019

Beverland, Michael B. (2006). "The 'real thing': Branding authenticity in the luxury wine trade". Journal of business research, v. 59, n. 2, pp. 251-258.

https://doi.org/10.1016/j.jbusres.2005.04.007

Bhattacharya, Subhajit (2017). "Does corporate social responsibility contribute to strengthen brand equity? An empirical study". International review on public and nonprofit marketing, v. 14, pp. 513-533.

https://doi.org/10.1007/s12208-017-0185-z

Bigné-Alcañiz, Enrique; Chumpitaz-Cáceres, Rubén; Currás-Pérez, Rafael (2010). "Alliances between brands and social causes: The influence of company credibility on social responsibility image". Journal of business ethics, v. 96, pp. 169-186. https://doi.org/10.1007/s10551-010-0461-x

Bigné-Alcañiz, Enrique; Currás-Pérez, Rafael; Sánchez-García, Isabel (2009). “Brand credibility in cause-related marketing: The moderating role of consumer values". Journal of product \& brand management, v. 18, n. 6, pp. $437-447$. https://doi.org/10.1108/10610420910989758

Borden, Jonathan (2019). Consumer attachment and corporate social advocacy: Leveraging political behaviors to bolster organization-public relationships. Doctoral dissertation. Siracuse University.

https://surface.syr.edu/etd/1111

Brammer, Stephen J.; Pavelin, Stephen (2006). "Corporate reputation and social performance: The importance of fit". Journal of management studies, v. 43, n. 3, pp. 435-455.

https://doi.org/10.1111/j.1467-6486.2006.00597.x

Carney, Dana R.; Jost, John T.; Gosling, Samuel D.; Potter, Jeff (2008). "The secret lives of liberals and conservatives: Personality profiles, interaction styles, and the things they leave behind". Political psychology, v. 29, n. 6, pp. 807-840. https://doi.org/10.1111/j.1467-9221.2008.00668.x

Chan, Eugene Y.; Palmeira, Mauricio (2021). "Political ideology moderates consumer response to brand crisis apologies for data breaches". Computers in human behavior, v. 121, 106801.

https://doi.org/10.1016/j.chb.2021.106801

Chang, Kabrina K. (2017). "Starbucks for president: The disappearing line between Government and business as agents for social change". Empresa y humanismo, v. 20, n. 1, pp. 35-64.

https://doi.org/10.15581/015.XX.1.35-64

CIS (2021). Barómetro de marzo 2021. Avance de resultados. Estudio n. 3313. Madrid: Centro de Investigaciones Sociológicas.

http://www.cis.es/cis/opencms/ES/NoticiasNovedades/InfoCIS/2021/Documentacion_3313.htmI 
Corcoran, Michael; Newman, Kenneth; Devasagayam, P. Raj (2016). “Consumer perception of corporate activism: strategic implication for marketing". International journal of academic research in business and social sciences, v. 6, n. 10, pp. 52-61.

https://doi.org/10.6007/IJARBSS/v6-i10/2331

De-la-Fuente-Sabaté, Juan-Manuel; De-Quevedo-Puente, Esther (2003). "Empirical analysis of the relationship between corporate reputation and financial performance: a survey of the literature". Corporate reputation review, v. 6 , $n$. 2, pp. 161-177.

https://doi.org/10.1057/palgrave.crr.1540197

Den-Hond, Frank; Rehbein, Kathleen A.; De-Bakker, Frank G. A.; Kooijmans-Van-Lankveld, Hilda (2014). "Playing on two chessboards: Reputation effects between corporate social responsibility (CSR) and corporate political activity (CPA)". Journal of management studies, v. 51, n. 5, pp. 790-813.

https://doi.org/10.1111/joms.12063

Dodd, Melissa D.; Supa, Dustin W. (2014). “Conceptualizing and measuring 'corporate social advocacy' communication: Examining the impact on corporate financial performance". Public relations journal, v. 8, n. 3, pp. 2-23. https://www.bellisario.psu.edu/assets/uploads/2014DODDSUPA.pdf

Dodd, Melissa D.; Supa, Dustin W. (2015). "Testing the viability of corporate social advocacy as a predictor of purchase intention". Communication research reports, v. 32, n. 4, pp. 287-293.

https://doi.org/10.1080/08824096.2015.1089853

Dowling, Grahame R. (2016). “Defining and measuring corporate reputations". European management review, v. 13, n. 3, pp. 207-223.

https://doi.org/10.1111/emre.12081

Du, Shuili; Bhattacharya, C. B.; Sen, Sankar (2010). "Maximizing business returns to corporate social responsibility (CSR): The role of CSR communication". International journal of management reviews, v. 12, n. 1, pp. 8-19. https://doi.org/10.1111/j.1468-2370.2009.00276.x

Eberl, Markus; Schwaiger, Manfred (2005). "Corporate reputation: disentangling the effects on financial performance". European journal of marketing, v. 39, n. 7/8, pp. 838-854.

https://doi.org/10.1108/03090560510601798

Edelman (2019). Edelman trust barometer special report: In brands we trust? Chicago: Edgecliffe. https://www.edelman.com/research/trust-barometer-special-report-in-brands-we-trust

Eilert, Meike; Nappier-Cherup, Abigail (2020). "The activist company: Examining a company's pursuit of societal change through corporate activism using an institutional theoretical lens". Journal of public policy and marketing, v. 39, n. 4, pp. 461-476.

https://doi.org/10.1177/0743915620947408

Erdem, Tülin; Swait, Joffre (2004). "Brand credibility, brand consideration and choice". Journal of consumer research, v. 31, n. 1, pp. 191-198.

https://doi.org/10.1086/383434

Ewing, Douglas R.; Allen, Chris T.; Ewing, Randall L. (2012). "Authenticity as meaning validation: an empirical investigation of iconic and indexical cues in a context of 'green' products". Journal of consumer behaviour, v. 11, n. 5, pp. 381-390. https://doi.org/10.1002/cb.1382

Fatma, Mobin; Rahman, Zillur; Khan, Imran (2015). "Building company reputation and brand equity through CSR: The mediating role of trust". International journal of bank marketing, v. 33, n. 6, pp. 840-856.

https://doi.org/10.1108/IJBM-11-2014-0166

Fernandes, Daniel; Mandel, Naomi (2014). "Political conservatism and variety-seeking". Journal of consumer psychology, v. 24, n. 1, p. 79-86.

https://doi.org/10.1016/j.jcps.2013.05.003

Fombrun, Charles J. (1996). Reputation: realizing value from the corporate image. Harvard Business School Press. ISBN: 9780875846330

Fombrun, Charles J.; Rindova, Violina (1996). Who's tops and who decides? The social construction of corporate reputations. Working paper. New York University, Stern School of Business, pp. 5-13.

Fombrun, Charles J.; Shanley, Mark (1990). "What's in a name? Reputation building and corporate strategy". Academy of management journal, v. 33, n. 2, pp. 233-258.

https://doi.org/10.5465/256324 
Fombrun, Charles J.; Van-Riel, Cees B. M. (2004). Fame \& fortune: how successful companies build winning reputations. New York: Prentice Hall. ISBN: 9780130937377

Fritz, Kristine; Schoenmüeller, Verena; Bruhn, Manfred (2017). “Authenticity in branding - Exploring antecedents and consequences of brand authenticity". European journal of marketing, v. 51, n. 2, pp. 324-348.

https://doi.org/10.1108/EJM-10-2014-0633

Gatzert, Nadine (2015). "The impact of corporate reputation and reputation damaging events on financial performance: empirical evidence from the literature". European management journal, v. 33, n. 6, pp. 485-499.

https://doi.org/10.1016/j.emj.2015.10.001

Godfrey, Paul C. (2005). "The relationship between corporate philanthropy and shareholder wealth: a risk management perspective". Academy of management review, v. 30, pp. 777-798.

https://doi.org/10.5465/amr.2005.18378878

Goldsmith, Ronald E.; Lafferty, Barbara A.; Newell, Stephen J. (2000). "The impact of corporate credibility and celebrity credibility on consumer reaction to advertisements and brands". Journal of advertising, v. 29, n. 3, pp. 43-54.

https://doi.org/10.1080/00913367.2000.10673616

Graham, Jesse; Haidt, Jonathan; Nosek, Brian A. (2009). "Liberals and conservatives rely on different sets of moral foundations". Journal of personality and social psychology, v. 96, n. 5, pp. 1029-1046.

https://doi.org/10.1037/a0015141

Grayson, Kent; Martinec, Radan (2004). "Consumer perceptions of iconicity and indexicality and their influence on assessments of authentic market offerings". Journal of consumer research, v. 31, n. 2, pp. 296-312.

https://doi.org/10.1086/422109

Hair, Joseph F.; Black, Will C.; Babin, Barry J.; Anderson, Rolph E.; Tatham, Ronald L. (2006). Multivariate data analysis, $6^{\text {th }}$ ed. Upper Saddle River, New Jersey: Pearson Prentice Hall. ISBN: 9780138132637

Hennig-Thurau, Thornsten; Groth, Markus; Paul, Michael; Gremler, Dwayne D. (2006). “Are all smiles created equal? How emotional contagion and emotional labor affect service relationships". Journal of marketing, v. 70, n. 3, pp. 58-73. https://doi.org/10.1509/jmkg.70.3.058

Hoffmann, Christian P.; Bronn, Peggy S.; Fieseler, Christian (2016). “A good reputation: Protection against shareholder activism". Corporate reputation review, v. 19, n. 1, pp. 35-46.

https://doi.org/10.1057/crr.2015.27

Holt, Douglas B. (2002). "Why do brands cause trouble? A dialectical theory of consumer culture and branding". Journal of consumer research, v. 29, n. 1, pp. 70-90.

https://doi.org/10.1086/339922

Hoppner, Jessica J.; Vadakkepatt, Gautam G. (2019). “Examining moral authority in the marketplace: a conceptualization and framework". Journal of business research, v. 95, pp. 417-427.

https://doi.org/10.1016/j.jbusres.2018.07.045

Hovland, Carl I.; Janis, Irving L.; Kelley, Harold H. (1953). Communication and persuasion: psychological studies of opinion change. New Haven: Yale University Press. ISBN: 9780300005738

Hydock, Chris; Paharia, Neeru; Weber, Thomas J. (2019). "The consumer response to corporate political advocacy: a review and future directions". Customer needs and solutions, v. 6, n. 3, pp. 76-83.

https://doi.org/10.1007/s40547-019-00098-x

Iyengar, Shanto; Westwood, Sean J. (2015). "Fear and loathing across party lines: New evidence on group polarization". American journal of political science, v. 59, n. 3, pp. 690-707.

https://doi.org/10.1111/ajps.12152

Joo, Soyoung; Miller, Elisabeth G.; Fink, Janet S. (2019). “Consumer evaluations of CSR authenticity: Development and validation of a multidimensional CSR authenticity scale". Journal of business research, v. 98, pp. 236-249.

https://doi.org/10.1016/j.jbusres.2019.01.060

Jørgensen, Poul E. F.; Isaksson, Maria (2015). “The compassionate organization: contesting the rhetoric of goodwill in public sector value statements". International journal of public sector management, v. 28, n. 1, pp. 72-83.

https://doi.org/10.1108/IJPSM-09-2013-0132

Jost, John T. (2006). "The end of the end of ideology". American psychologist, v. 61, n. 7, pp. 651-670.

https://doi.org/10.1037/0003-066X.61.7.651

Jost, John T.; Glaser, Jack; Kruglanski, Arle W.; Sulloway, Frank J. (2003). "Political conservatism as motivated social cognition". Psychological bulletin, v. 129, n. 3, pp. 339-375.

https://doi.org/10.1037/0033-2909.129.3.339 
Jost, John T.; Hunyady, Orsolya (2003). "The psychology of system justification and the palliative function of ideology". European review of social psychology, v. 13, n. 1, pp. 111-153. https://doi.org/10.1080/10463280240000046

Jost, John T.; Langer, Melanie; Singh, Vishal (2017). "The politics of buying, boycotting, complaining, and disputing: An extension of the research program by Jung, Garbarino, Briley, and Wynhausen". Journal of consumer research, v. 44, n. 3, pp. 503-510.

https://doi.org/10.1093/jcr/ucx084

Jung, Kiju; Garbarino, Ellen; Briley, Donnel A.; Wynhausen, Jesse (2017). "Blue and red voices: effects of political ideology on consumers' complaining and disputing behavior". Journal of consumer research, v. 44, n. 3, pp. 477-499. https://doi.org/10.1093/jcr/ucx037

Keller, Kevin L. (1998). Strategic brand management: building, measuring and managing brand equity. New Jersey: Prentice-Hall. ISBN: 9780131201156

Keller, Kevin L.; Lehmann, Donald R. (2006). "Brands and branding: research findings and future priorities". Marketing science, v. 25, n. 6, pp. 740-759.

https://doi.org/10.1287/mksc.1050.0153

Kim, Sora; Lee, Yoon (2012). "The complex attribution process of CSR motives”. Public relations review, v. 38, n. 1, pp. 168-170.

https://doi.org/10.1016/j.pubrev.2011.09.024

Kim, Jeehye C.; Park, Brian; Dubois, David (2018). “How consumers' political ideology and status-maintenance goals interact to shape their desire for luxury goods". Journal of marketing, v. 82, n. 6, pp. 132-149.

https://doi.org/10.1177/0022242918799699

King, Brayden G. (2008). "A political mediation model of corporate response to social movement activism”. Administrative science quarterly, v. 53, n. 3, pp. 395-421.

https://doi.org/10.2189/asqu.53.3.395

Korschun, Daniel; Martin, Kelly D.; Vadakkepatt, Gautham (2020). "Marketing's role in understanding political activity". Journal of public policy \& marketing, v. 39, n. 4, pp. 378-387.

https://doi.org/10.1177/0743915620949261

Korschun, Daniel; Rafieian, Hoori; Aggarwal, Anubhav; Swain, Scott D. (2019). "Taking a stand: consumer responses when companies get (or don't get) political". SSRN, 2806476.

https://doi.org/10.2139/ssrn.2806476

Lafferty, Barbara A. (2007). "The relevance of fit in a cause-brand alliance when consumers evaluate corporate credibility". Journal of business research, v. 60, n. 5, pp. 447-453.

https://doi.org/10.1016/J.JBUSRES.2006.09.030

Lafferty, Barbara A.; Goldsmith, Ronald E. (1999). “Corporate credibility's role in consumers' attitudes and purchase intentions when a high versus a low credibility endorser is used in the ad". Journal of business research, v. 44, n. 2, pp. 109-116. https://doi.org/10.1016/S0148-2963(98)00002-2

Lai, Chi-Shiun; Chih, Chiu-Jen; Yang, Chin-Fang; Pai, Da-Chang (2010). "The effects of corporate social responsibility on brand performance: The mediating effect of industrial brand equity and corporate reputation". Journal of business ethics, v. 95, n. 3, pp. 457-469.

https://doi.org/10.1007/s10551-010-0433-1

Lee, Sun-Youg; Zhang, Weiwu; Abitbol, Alan (2019). "What makes CSR communication lead to CSR participation? Testing the mediating effects of CSR associations, CSR credibility, and organization-public relationships". Journal of business ethics, v. 157, n. 2, pp. 413-429.

https://doi.org/10.1007/s10551-017-3609-0

Lin, Tom C. W. (2018). "Incorporating social activism”. Boston University law review, v. 98, pp. 1535-1605. https://www.bu.edu/bulawreview/files/2019/01/LIN.pdf

Mahrinasari, M. S. (2019). "Determinants of brand equity: communication of corporate social responsibility (CSR) versus CSR itself and company credibility". Contemporary economics, v. 13, n. 3, pp. 317-334.

http://www.ce.vizja.pl/en/issues/volume/13/issue/3\#art580

Manfredi-Sánchez, Juan-Luis (2019). “Activismo político de los presidentes de empresa del IBEX 35 ante los retos políticos, sociales y medioambientales". El profesional de la información, v. 28, n. 5, e280505.

https://doi.org/10.3145/epi.2019.sep.05 
Martín-de-Castro, Gregorio; Navas-López, José-Emilio; López-Sáez, Pedro (2006). “Business and social reputation: exploring the concept and main dimensions of corporate reputation". Journal of business ethics, v. 63, n. 4, pp. 361-370. https://doi.org/10.1007/s10551-005-3244-z

Masip, Pere; Suau, Jaume; Ruiz-Caballero, Carlos (2020). "Percepciones sobre medios de comunicación y desinformación: ideología y polarización en el sistema mediático español”. Profesional de la información, v. 29, n. 5, e290527. https://doi.org/10.3145/epi.2020.sep.27

Matten, Dirk; Crane, Andrew (2005). "Corporate citizenship: Toward an extended theoretical conceptualization". Academy of management review, v. 30, n. 1, pp. 166-179.

https://doi.org/10.5465/amr.2005.15281448

McCroskey, James C.; Teven, Jason J. (1999). "Goodwill: A reexamination of the construct and its measurement". Communication monographs, v. 66, n. 1, pp. 90-103.

https://doi.org/10.1080/03637759909376464

McDonnell, Mary-Hunter; King, Brayden (2013). "Keeping up appearances: Reputational threat and impression management after social movement boycotts". Administrative science quarterly, v. 58, n. 3, pp. 387-419.

https://doi.org/10.1177/0001839213500032

McShane, Lindsay; Cunningham, Peggy (2012). "To thine own self be true? Employees' judgments of the authenticity of their organization's corporate social responsibility program". Journal of business ethics, v. 108, n. 1, pp. 81-100.

https://doi.org/10.1007/s10551-011-1064-x

Mohr, Lois A.; Webb, Deborah J.; Harris, Katherine E. (2001). "Do consumers expect companies to be socially responsible? The impact of corporate social responsibility on buying behavior". Journal of consumer affairs, v. 35, n. 1, pp. 45-72. https://doi.org/10.1111/j.1745-6606.2001.tb00102.x

Monfort, Abel; Villagra, Nuria; López-Vázquez, Belén (2019). “Exploring stakeholders' dialogue and corporate social responsibility (CSR) on Twitter". El profesional de la información, v. 28, n. 5, e280513.

https://doi.org/10.3145/epi.2019.sep.13

Moorman, Christine (2020). "Commentary: Brand activism in a political world". Journal of public policy \& marketing, v. 39, n. 4, pp. 388-392.

https://doi.org/10.1177/0743915620945260

Moulard, Julie G.; Raggio, Randle D.; Folse, Judith A. G. (2016). "Brand authenticity: Testing the antecedents and outcomes of brand management's passion for its products". Psychology \& marketing, v. 33, n. 6, pp. 421-436. https://doi.org/10.1002/mar.20888

Mukherjee, Sourjo; Althuizen, Niek (2020). "Brand activism: Does courting controversy help or hurt a brand?". International journal of research in marketing, v. 37, n. 4, pp. 772-788.

https://doi.org/10.1016/j.ijresmar.2020.02.008

Nalick, Michael; Josefy, Matthew; Zardkoohi, Asghar; Bierman, Leonard (2016). “Corporate sociopolitical involvement: a reflection of whose preferences?". Academy of management perspectives, v. 30, n. 4, pp. 384-403.

https://doi.org/10.5465/amp.2015.0033

Newell, Stephen J.; Goldsmith, Ronald E. (2001). "The development of a scale to measure perceived corporate credibility". Journal of business research, v. 52, n. 3, pp. 235-247.

https://doi.org/10.1016/S0148-2963(99)00104-6

Odriozola, María D.; Baraibar-Díez, Elisa (2017). "Is corporate reputation associated with quality of CSR reporting? Evidence from Spain". Corporate social responsibility and environmental management, v. 24, n. 2, pp. 121-132. https://doi.org/10.1002/csr.1399

Ordabayeva, Nailya; Fernandes, Daniel (2018). "Better or different? How political ideology shapes preferences for differentiation in the social hierarchy". Journal of consumer research, v. 45, n. 2, pp. 227-250. https://doi.org/10.1093/jcr/ucy004

Paek, Hye-Jin; Nelson, Michelle R. (2009). "To buy or not to buy: Determinants of socially responsible consumer behavior and consumer reactions to cause-related and boycotting ads". Journal of current issues \& research in advertising, $v$. 31, n. 2, pp. 75-90.

https://doi.org/10.1080/10641734.2009.10505267

Pappu, Ravi; Quester, Pascale G.; Cooksey, Ray W. (2005). "Consumer-based brand equity: improving the measurement-empirical evidence". Journal of product \& brand management, v. 14, n. 3, pp. 143-154.

https://doi.org/10.1108/10610420510601012 
Parcha, Joshua M.; Kingsley-Westerman, Catherine Y. (2020). "How corporate social advocacy affects attitude change toward controversial social issues". Management communication quarterly, v. 34, n. 3, pp. 350-383.

https://doi.org/10.1177/0893318920912196

Park, Jongchul; Lee, Hanjoon; Kim, Chankon (2014). “Corporate social responsibilities, consumer trust and corporate reputation: South Korean consumers' perspectives". Journal of business research, v. 67, n. 3, pp. 295-302.

https://doi.org/10.1016/j.jbusres.2013.05.016

Pérez-Morote, Rosario; Pontones-Rosa, Carolina; Núñez-Chicharro, Montserrat (2020). "The effects of e-government evaluation, trust and the digital divide in the levels of e-government use in European countries". Technological forecasting and social change, v. 154, 119973.

https://doi.org/10.1016/j.techfore.2020.119973

Pérez-Ruiz, Andrea; Rodríguez-del-Bosque, Ignacio (2015). “How customer novelty seeking influences customer CSR perceptions". Marketing intelligence \& planning, v. 33, n. 4, pp. 486-507.

https://doi.org/10.1108/MIP-07-2014-0140

Pintado-Blanco, Teresa; Sánchez-Herrera, Joaquín; López-Aza, Carlota (2020). “Activismo corporativo: ¿moda o estrategia de comunicación de marca?". Harvard Deusto. Márketing y ventas, n. 162, pp. 6-13.

https://www.harvard-deusto.com/activismo-corporativo-moda-o-estrategia-de-comunicacion-de-marca

Ponzi, Leonard J.; Fombrun, Charles J.; Gardberg, Naomi A. (2011). “RepTrak ${ }^{\mathrm{TM}}$ pulse: Conceptualizing and validating a short-form measure of corporate reputation". Corporate reputation review, v. 14, n. 1, pp. 15-35.

https://doi.org/10.1057/crr.2011.5

Pressgrove, Geah; Kim, Carolyn (2018). "Stewardship, credibility and political communications: A content analysis of the 2016 election". Public relations review, v. 44, n. 2, pp. 247-255.

https://doi.org/10.1016/j.pubrev.2018.01.003

Reiljan, Andrés (2020). "Fear and loathing across party lines' (also) in Europe: affective polarisation in European party systems". European journal of political research, v. 59, n. 2, pp. 376-396.

https://doi.org/10.1111/1475-6765.12351

Rim, Hyejoon; Dong, Chuqing (2018). "Trust and distrust in society and public perception of CSR: a cross-cultural study". Social responsibility journal, v. 14, n. 1.

https://doi.org/10.1108/SRJ-01-2017-0016

Rim, Hyejoon; Lee, YoungAh; Yoo, Sanglim (2020). "Polarized public opinion responding to corporate social advocacy: social network analysis of boycotters and advocators". Public relations review, v. 46, n. 2, 101869.

https://doi.org/10.1016/j.pubrev.2019.101869

Roberts, Peter W.; Dowling, Grahame R. (2002). "Corporate reputation and sustained superior financial performance". Strategic management journal, v. 23, n. 12, pp. 1077-1093.

https://doi.org/10.1002/smj.274

Rothenhoefer, Lisa M. (2019). "The impact of CSR on corporate reputation perceptions of the public. A configurational multi-time, multi-source perspective". Business ethics: A European review, v. 28, n. 2, pp. 141-155.

https://doi.org/10.1111/beer.12207

Saeidi, Sayedeh-Parastoo; Sofian, Saudah; Saeidi, Parvaneh; Saeidi, Sayyedeh-Parisa; Saaeidi, Seyyed-Alireza (2015). "How does corporate social responsibility contribute to firm financial performance? The mediating role of competitive advantage, reputation, and customer satisfaction". Journal of business research, v. 68, n. 2, pp. 341-350.

https://doi.org/10.1016/j.jbusres.2014.06.024

Sarkar, Christian; Kotler, Philip (2018). “Brand activism. From purpose to action”. Houston: Idea Bite Press. ISBN: 9780 990576792

Scherer, Andreas G.; Palazzo, Guido; Matten, Dirk (2014). "The business firm as a political actor: A new theory of the firm for a globalized world”. Business \& society, v. 53, pp. 143-156.

https://doi.org/10.1177/0007650313511778

Sen, Sankar; Bhattacharya, C. B. (2001). "Does doing good always lead to doing better? Consumer reactions to corporate social responsibility". Journal of marketing research, v. 38, n. 2, pp. 225-243.

https://doi.org/10.1509/jmkr.38.2.225.18838

Sobande, Francesca (2019). "Woke-washing: 'intersectional' femvertising and branding 'woke' bravery". European journal of marketing, v. 54, n. 11, pp. 2723-2745.

https://doi.org/10.1108/EJM-02-2019-0134 
Stanley, Vincent (2020). "Commentary: Patagonia and the business of activism". Journal of public policy \& marketing, v. 39, n. 4, pp. 393-395.

https://doi.org/10.1177/0743915620948864

Stephan, Ute; Patterson, Malcom; Kelly, Ciara; Mair, Johanna (2016). “Organizations driving positive social change: A review and an integrative framework of change processes". Journal of management, v. 42, n. 5, pp. 1250-1281. https://doi.org/10.1177/0149206316633268

Torres, Anna; Bijmolt, Tammo H. A.; Tribó, Josep A.; Verhoef, Peter (2012). “Generating global brand equity through corporate social responsibility to key stakeholders". International journal of research in marketing, v. 29, n. 1, pp. 13-24. https://doi.org/10.1016/j.ijresmar.2011.10.002

Turban, Daniel B.; Cable, Daniel M. (2003). "Firm reputation and applicant pool characteristics”. Journal of organizational behavior, v. 24, n. 6, pp. 733-751.

https://doi.org/10.1002/job.215

Ulver, Sofia; Laurell, Christofer (2020). "Political ideology in consumer resistance: Analyzing far-right opposition to multicultural marketing". Journal of public policy \& marketing, v. 39, n. 4, pp. 477-493.

https://doi.org/10.1177/0743915620947083

Valera-Ordaz, Lidia; Doménech-Beltrán, Jaume (2020). "Perfil sociodemográfico y actitudes políticas de los grupos a favor y en contra de limitar la libre circulación de información durante la pandemia". Profesional de la información, v. 29, n. 6, e290616.

https://doi.org/10.3145/epi.2020.nov.16

Van-Beurden, Pieter; Gössling, Tobias (2008). "The worth of values. A literature review on the relation between corporate social and financial performance". Journal of business ethics, v. 82, n. 2, 407.

https://doi.org/10.1007/s10551-008-9894-x

Vredenburg, Jessica; Kapitan, Sommer; Spry, Amanda; Kemper, Joya A. (2020). "Brands taking a stand: Authentic brand activism or woke washing?”. Journal of public policy \& marketing, v. 39, n. 4, pp. 444-460. https://doi.org/10.1177/0743915620947359

Vredenburg, Jessica; Spry, Amanda; Kemper, Joya A.; Kapitan, Sommer (2018). "Woke washing: What happens when marketing communications don't match corporate practice". The conversation, December 5.

https://theconversation.com/woke-washing-what-happens-when-marketing-communications-dont-match-corporatepractice-108035

Waddock, Sandra A.; Graves, Samuel B. (1997). "The corporate social performance-financial performance link". Strategic management journal, v. 18, n. 4, pp. 303-319.

https://doi.org/10.1002/(SICI)1097-0266(199704)18:4\%3C303::AID-SMJ869\%3E3.0.CO;2-G

Wettstein, Florian; Baur, Dorothea (2016). "Why should we care about marriage equality?: political advocacy as a part of corporate responsibility". Journal of business ethics, v. 138, n. 2, pp. 199-213.

https://doi.org/10.1007/s10551-015-2631-3

Wilcox, Dennis L. (2019). "Dialogic communication theory in the age of corporate activism: a postmodern perspective". Communication and media in Asia Pacific, v. 2, n. 1.

https://so01.tci-thaijo.org/index.php/CMAP/article/view/163778

Yoo, Boonghee; Donthu, Naveen (2001). “Developing and validating a multidimensional consumer-based brand equity scale". Journal of business research, v. 52, n. 1.

https://doi.org/10.1016/S0148-2963(99)00098-3

Yoo, Boonghee; Donthu, Naveen; Lee, Sungho (2000). “An examination of selected marketing mix elements and brand equity". Journal of the Academy of Marketing Science, v. 28, n. 2, pp. 195-211.

https://doi.org/10.1177/0092070300282002

Zasuwa, Grzegorz (2019). "Do consumers really care about organisational motives behind CSR? The moderating role of trust in the company". Social responsibility journal, v. 15, n. 8, pp. 977-991.

https://doi.org/10.1108/SRJ-08-2017-0140 